\title{
Performance evaluation of three rapid screening assays for detection of antibodies to hepatitis $C$ virus in Cameroon
}

\author{
Clavel Landry Kouam Fondjo ${ }^{1}$, Paul Alain Tagnouokam Ngoupo ${ }^{1}$, Laure Ngono ${ }^{1}$, Jean-Christophe Plantier ${ }^{2}$ \\ and Richard Njouom ${ }^{1 *}$ (D)
}

\begin{abstract}
Objective: This study was aimed at evaluating the performance of three CE-marked rapid diagnostic tests (RDTs): Multisure-HCV, First Response ${ }^{\circledR}$ and Toyo ${ }^{\circledR}$; for screening anti- HCV antibody using plasma samples.

Results: Overall, 200 plasma samples were used. Sensibility and specificity of these RDTs range from 71 to 99 and 78 to $100 \%$ respectively. Multisure scored a sensitivity at 99\% (95\% Cl 97-100\%) and First Response reached a specificity at 90\% (95\% Cl 85-94.9\%). Further studies should be conducted to establish an algorithm using these RTDs for the detection of HCV infection in Cameroon.
\end{abstract}

Keywords: Cameroon, HCV, Rapid diagnostic test, Performance, Plasma

\section{Introduction}

In Cameroon, the prevalence of hepatitis $\mathrm{C}$ virus (HCV) infection is estimated at $1.1 \%$ from the samples of the 2011 Demographic Health Survey [1]. This prevalence is estimated at $0.81 \%$ for the $15-49$ year's group and $2.51 \%$ for all individuals aged $\geq 15$ years. It is estimated that about 195,000 individuals in Cameroon were viremic in 2011 including 92,000 adults aged $15-59$ years and 103,000 individuals aged $\geq 60$ years [1]. Diagnosis of $\mathrm{HCV}$ infection is based on the use of enzyme-linked immunoassays for the detection of $\mathrm{HCV}$ antibody followed by a molecular confirming test in case of positivity [2]. However, accessibility to these conventional assays is a challenge for the majority of people infected with $\mathrm{HCV}$ especially for those living in peripheral regions due to the high cost of these assays as well as their availability [3]. Diagnosis and testing remains a challenge for the elimination of viral hepatitis including HCV. According to WHO reports, only 1 in 5 people living with hepatitis

*Correspondence: njouom@pasteur-yaounde.org

${ }^{1}$ Virology Department, Centre Pasteur of Cameroon, PO Box 1274 Yaounde, Cameroon

Full list of author information is available at the end of the article
C, were aware of their infection in 2015 [3]. Therefore, countries need to improve policies and programs to increase diagnosis. Rapid diagnostic tests (RDTs) represent an alternative solution to conventional HCV tests. Recently, certified RDTs for HCV have been approved to track down this infection [2]. The WHO prequalification program revealed that only two HCV RDTs (SD Bioline HCV from Standard Diagnostics and OraQuick HCV Rapid Antibody Test from OraSure Technologies) have been prequalified so far [4]. However, since 2014 in Europe, the French "Haute Autorité de Santé" (HAS) has evaluated CE-marked HCV RDTs and found that these tests had good performance. In addition, HAS recommends the use of CE-marked HCV RDTs that feature the European Union standard (100\% of sensitivity and specificity $\geq 99 \%)[5,6]$.

Data collected from the Ministry of Public Health in Cameroon showed that none of the HCV RDTs used in health facilities is qualified. Therefore this study aimed at evaluating the performances of three CE-marked HCV RDTs for the screening of anti-HCV antibodies using plasma samples collected in Resource Limited setting. These RTDs included: i) Multisure HCV Antibody Assay (MP Biomedical, Asia Pacific, Singapore), ii) First 
Response HCV Card Test (Premier Medical Corporation Ltd, Watchung, New Jersey), and iii) Toyo ${ }^{\circledR}$ Anti HCV Test (Türklab, Izmir, Turkey).

\section{Main text \\ Methods \\ Study sample and laboratory analysis}

From November 2016 to February 2017, we carried out a cross-sectional study on 200 plasma (including 100 positive and 100 negative) stored at $-80^{\circ} \mathrm{C}$ at Centre Pasteur of Cameroon (CPC). These samples were previously screened for anti-HCV antibodies at the same laboratory using an automated chemiluminescent microparticle immunoassay (Architect anti-HCV assay; Abbott Diagnostics, Wiesbaden, Germany). Performance (sensitivity, specificity, positive predictive value and negative predictive value) of Multisure $\mathrm{HCV}$ Antibody Assay, First Response ${ }^{\circledR}$ HCV Card Test, and Toyo ${ }^{\circledR}$ Anti HCV Test were assessed for anti-HCV antibodies screening using plasma samples.

Multisure HCV Antibody is a qualitative immunochromatographic assay for the detection of antibodies to Core, NS3, NS4 and NS5 HCV proteins in human whole blood, plasma or serum. Each protein is revealed in a separate and distinct line in the test within $15 \mathrm{~min}$. First Response HCV Card Test and Toyo ${ }^{\circledR}$ Anti HCV Test are chromatographic immunoassays for qualitative detection of the antibodies against hepatitis $C$ virus in human serum, plasma or whole blood samples. HCV antigens (Core, NS3, NS4 and NS5) are immobilized at only one test line and the result is obtained within $20 \mathrm{~min}$.

The RDTs were performed following the manufacturer's instructions, and the interpretation was done by three independent blinded laboratory technicians. No specific control was included in the study other than the internal control which is incorporated in each assay.

\section{Statistical analysis}

Data was analyzed with SPSS statistics version 20.0.0 (IBM Corporation, USA). The relevant accuracy estimates of the three RDTs were expressed using the Pearson Chi square test, based on the result of Architect
anti-HCV assay considered as Gold standard. The results were estimated with $95 \%$ confidence intervals (CI), and the difference was considered statistically significant with a $\mathrm{p}<0.05$.

\section{Results}

We assessed the performance of Multisure HCV Antibody Assay, First Response ${ }^{\circledR}$ HCV Card Test and Toyo ${ }^{\circledR}$ Anti HCV Test in a total of 200; 140 and 150 plasma samples, respectively. The shortage in the remaining samples may explain the observed inequality in the number of RDTs used. The four parameters analyzed to assess the performances of these RDTs were the sensitivity (Se), the specificity (Sp), the positive predictive value (PPV), and the negative predictive value (NPV).

Multisure featured a clinical sensitivity of 99\% (95\% CI $97-100 \%)$ followed by First Response ${ }^{\circledR}$ 96\% (95\% CI $92.7-99.2 \%)$ and Toyo $^{\circledR}$ 96\% (95\% CI $92.8-99.1 \%$ ) (Table 1). As concerns the specificity, First Response ${ }^{\circledR}$ scored 90\% (95\% CI 85-94.9\%) followed by Multisure 83\% (95\% CI: 77.7-82.2\%) and Toyo ${ }^{\circledR} 78 \%$ (95\% CI 71.384.6\%) (Table 1). However, the sensitivity and the specificity were not significantly different among the three RDTs $(p=0.36$ and $p=0.24$ respectively). Regarding the predictive values, First Response ${ }^{\circledR}$ scored the best PPV at 96\% (95\% CI 92.7-99.2\%); meanwhile Multisure reached the best NPV at 99\% (95\% CI 97.6-100) (Table 1).

Since different serum samples were tested with each RDT, we assessed the performance of these tests with only the 90 overlapping samples to compare assay performance among all of the tests. Multisure had a sensitivity of $100 \%$ followed by First Response ${ }^{\circledR}$ and Toyo ${ }^{\circledR}, 96 \%$ (95\% CI 91.7-100\%) (Table 2). As concerns the specificity, Multisure had a specificity of $92.5 \%$ (95\% CI 87.5-97.4\%) followed by First Response ${ }^{\circledR}$ 90\% (95\% CI 84.7-95.2\%) and Toyo ${ }^{\circledR}, 80 \%$ (95\% CI 74.5-85.4\%) (Table 2). However, the sensitivity and the specificity were not significantly different among the three RDTs $(p=0.35$ and $p=0.20$ respectively). Finally based on the ARCHITECT anti$\mathrm{HCV}$ test results, we obtained 50/3 (true positive/false positive) and 0/37 (true negative/false negative) samples among the 90 overlapping samples with Multisure, 48/4

Table 1 Overall comparison of the three rapid diagnostic tests (RDTs) evaluated for the screening of anti-HCV antibodies

\begin{tabular}{lllll}
\hline HCV RDTs & Se & Sp & PPV & NPV \\
\% (95\% Cl) & (95\% Cl) & (95\% Cl) & 99 (97.6-100) \\
\hline Multisure HCV Antibody assay & $99(97-100)$ & $83(77.7-88.2)$ & $85(80-89.9)$ & $90(85-94.9)$ \\
First Response ${ }^{\circledR}$ HCV Card Test & $96(92.7-99.2)$ & $90(85-94.9)$ & $96(92.7-99.2)$ & $90.7(86-95.3)$ \\
Toyo ${ }^{\circledR}$ Anti HCV Test & $96(92.8-99.1)$ & $78(71.3-84.6)$ & $89.7(83.9-94)$ & \\
\hline
\end{tabular}

Se, sensibility; Sp, specificity; PPV, predictive positive value; NPV, negative predictive value; HCV, hepatitis C virus; RDTs, rapid diagnostic tests; Cl, confidence interval 
Table 2 Comparison of the three rapid diagnostic tests (RDTs) evaluated for screening anti-HCV with only overlapping samples

\begin{tabular}{|c|c|c|c|c|c|c|c|c|}
\hline HCV RDTs & Se $(95 \% \mathrm{Cl})$ & $\mathrm{Sp}(95 \% \mathrm{Cl})$ & PPV $(95 \% \mathrm{Cl})$ & NPV $(95 \% \mathrm{Cl})$ & $\mathrm{TP}(\mathrm{n})$ & $\mathrm{FP}(\mathrm{n})$ & $\mathrm{TN}(\mathrm{n})$ & FN (n) \\
\hline Multisure HCV Antibody assay & 100 & $92.5(87.5-97.4)$ & $94.3(89.2-98.7)$ & 100 & 50 & 3 & 37 & 0 \\
\hline First Response ${ }^{\circledR}$ HCV Card Test & $96(91.7-100)$ & $90(84.7-95.2)$ & $92.3(87.3-97.2)$ & $94.7(90.1-99.3)$ & 48 & 4 & 36 & 2 \\
\hline Toyo ${ }^{\circledR}$ Anti HCV Test & $96(91.7-100)$ & $80(74.5-85.4)$ & $85.7(80.3-91.1)$ & $94.1(89.4-98.8)$ & 48 & 8 & 32 & 2 \\
\hline
\end{tabular}

Se Sensitivity, Sp specificity, PPV predictive positive value, NPV negative predictive value, $T P$ true positive, $F P$ false positive, $T N$ true negative, $F N$ false negative, $n$ number, $H C V$ hepatitis $C$ virus, RDTs rapid diagnostic tests, $C l$ confidence interval

and $36 / 2$ with First Response ${ }^{\circledR}$ and $48 / 8$ and $32 / 2$ with Toyo ${ }^{\circledR}$ (Table 2).

\section{Discussion}

This study showed none of the RDTs evaluated reached the European Union standards (100\% of sensitivity and specificity $\geq 99 \%$ ). These standards are based on different studies carried out in Europe, where conditions in realizing assays are practically different from those in resource limited countries in term of respect of quality assurance (supply chain reliability, implementation of a standardized logbook). The WHO (World Health Organization) has clearly demonstrated the high probability in obtaining false results using RDTs in case of non-respect of quality assurance [7]. Furthermore, the studied populations (North versus South) could also explain the difference observed in this study and European Union standards in term of specificity. Nevertheless, the results obtained from these RDTs are not significantly satisfactory and suggest that further studies should be conducted to establish an algorithm using these RTDs for the detection of HCV infection in Cameroon. The strategy used for HIV diagnosis based on two RDTs [8]: the most sensitive RDTs as the first, then the most specific assay in case of positivity, could be evaluated for HCV screening.

\section{Conclusion}

None of the three RDTs evaluated met the European Union standards. However, the performances obtained are crucial indications for the Ministry of Public Health of Cameroon on the choice of RDTs to be used regarding their performance, and especially to promote assessment of HCV RDTs before implementation. Therefore, further studies should be conducted to establish an algorithm using these RTDs for the detection of $\mathrm{HCV}$ infection in Cameroon.

\section{Limitations}

The evaluation of RDTs was only based on plasma. We did not consider that HCV serology can also be performed on the whole blood, serum and crevicular fluid. We could have worked with these four types of samples on the same panel to see if there are differences in the results.

\begin{abstract}
Abbreviations
DBS: dried blood spot; RDTs: rapid diagnostic tests; HCV: hepatitis C virus; HIV: human immunodeficiency virus; Se: sensitivity; Sp: specificity; PPV: positive predictive value; NPV: negative predictive value.
\end{abstract}

\section{Authors' contributions}

LKF collected data, performed laboratory analysis and statistical analysis. PATN and LN reviewed the data and interpreted the results. LKF, PATN and LN wrote the first draft of the manuscript. RN and JCP conceived, designed and conducted the study. All the authors substantially participated in the work, critically revised the manuscript and approved the final version.

\section{Author details \\ ${ }^{1}$ Virology Department, Centre Pasteur of Cameroon, PO Box 1274 Yaounde, Cameroon. ${ }^{2}$ Hôpital Charles Nicolle, Centre Hospitalier Universitaire de Rouen,} 1 rue de Germont, Rouen, France.

\section{Acknowledgements}

The authors are grateful to all colleagues at the Centre Pasteur of Cameroon for their direct or indirect contribution to the successful accomplishment of this study.

\section{Competing interests}

The authors declare that they have no competing interests.

Availability of data and materials

All data generated or analysed during this study are Available from RN.

Consent for publication

Not applicable.

\section{Ethics approval and consent to participate}

The study was approved by the ethics committee of the Catholic University of Central Africa/School of Health Science (N²016/0393/CEIRSH/ESS/MIM).

\section{Funding}

This work was supported by Centre Pasteur of Cameroon (CPC) for the study, collection, analysis and interpretation of data; and NEPHROTEK (France) for having provided the RDTs.

\section{Publisher's Note}

Springer Nature remains neutral with regard to jurisdictional claims in published maps and institutional affiliations. 
Received: 24 January 2018 Accepted: 1 June 2018

Published online: 05 June 2018

\section{References}

1. Njouom R, Siffert I, Texier G, Lachenal G, Tejiokem MC, Pepin J, et al. The burden of hepatitis C virus in Cameroon: spatial epidemiology and historical perspective. J Viral Hepat. 2018. https://doi.org/10.1111/jvh.12894

2. CDC. Testing for HCV infection: an update of guidance for clinicians and laboratorians. MMWR Morb Mortal Wkly Rep. 2013;62:362-5.

3. WHO. http://www.who.int/mediacentre/news/releases/2017/hepatitis-ccure/en/. 2017. Accessed 18 Apr 2018.

4. WHO. http://www.who.int/mediacentre/factsheets/fs164/fr/. 2016. Accessed 4 Nov 2016
5. HAS. Place des tests rapides d'orientation diagnostique (TROD) dans la stratégie de dépistage de l'hépatite C. 2016.

6. HAS. Place des tests rapides d'orientation diagnostique (TROD) dans la stratégie de dépistage de l'hépatite C. 2014.

7. Adler M, Behel S, Duncan D, Houston J, Kalou M, Lasry A, et al. Consolidated guidelines on HIV testing services: 5 Cs: consent, confidentiality, counselling, correct results and connection 2015. World Health Organization 2015; 2015

8. MSP-Cameroon. Guide national de prise en charge des personnes vivant avec le VIH/SIDA - Cameroun: Chapitre 2: counselling: Algorithme national pour le depistage du VIH. n.d. http://collections.infocollections .org/whocountry/fr/d/Js6882f/5.1.html. Accessed 30 May 2017.
Ready to submit your research? Choose BMC and benefit from:

- fast, convenient online submission

- thorough peer review by experienced researchers in your field

- rapid publication on acceptance

- support for research data, including large and complex data types

- gold Open Access which fosters wider collaboration and increased citations

- maximum visibility for your research: over $100 \mathrm{M}$ website views per year

At BMC, research is always in progress.

Learn more biomedcentral.com/submissions 